\title{
The effect of system quality and service quality toward using m-commerce service, based on con- sumer perspective
}

\author{
Ibrahim A. Abu AISondos ${ }^{a^{*}}$ and Anas A. Mohammad Salameh ${ }^{b}$
}

${ }^{a}$ Assistant Professor, Department of Management Information Systems, College of Administrative Sciences, Applied Science University, Bahrain

${ }^{b}$ Assistant Professor, Department of Management Information Systems, College of Business Administration, Prince Sattam bin Abdulaziz University, 165 Al-Kharj 11942, Saudi Arabia

\section{CHRONICLE ABSTRACT}

Article history:
Received: February 16, 2020
Received in revised format:
March 222020
Accepted: March 22, 2020
Available online:
March 28, 2020
Keywords:
M-commerce
Customer perceived service qual-
ity
CPSQ
Service quality

\begin{abstract}
There is no doubt that $\mathrm{m}$-commerce a paramount contributor to many companies and economies in many areas around the world. Thus, changes the way of m-commerce companies becomes very important in order to gain more profit. The main reason for this study is to increase the customers' awareness toward using mobile for purchasing purposes. The study reveals how $\mathrm{m}$-commerce process changes the role of trading from the traditional way to the electronic one. The objective of this research is to determine the impact of ease of use and perceived cognitive control on consumer perception for using m-commerce system. Data of the survey were collected from Arab Open University (AOU), the number of participants was 618 . The results indicated that all variables affected consumers toward using mobile for purchasing purposes in coming future.
\end{abstract}

(C) 2020 by the authors; licensee Growing Science, Canada

\section{Introduction}

Today the technology brought a lot of changes to our daily life; the advantage of information technology (IT) is that it allows us to conduct our work in novel, more efficient and effective ways, not possible in the past (Klopfer, Osterweil, Groff, \& Haas, 2009). Development of time and location-bound commerce can be divided into three stages. The first stage is a traditional formal commerce, in which customers and vendors have to go to the shop themselves, where a one-on-one interaction takes place among the customers and the vendors. In the second stage, that is e-commerce, various media, like text, audio, video, and hypertext are used. The third stage is known as Mobile commerce (m-commerce), where business is conducted, using modern devices, such as Palm Pocket, Personal Computer (PC), Personal Digital Assistant (PDA), two-way pagers and Cellular Phones.

\section{Problem Statement}

According to Mallat et al. (2009), the wireless technology opens new opportunities comparing to the one available in the old wired technology, so, on wired the limitation on access to the web appeared as well as the functionality offered by wired inflexible comparing to the one in wireless technologies. Indeed, since mobile devices start growing, the consumer does not need to travel to purchase the products or even services. There are only few studies on consumer perception toward using mobile for purchasing purposes. This study tries to know the effect of perceived cognitive control (PCC), and ease of use * Corresponding author. Tel.: + 97338423095

E-mail address: Ibrahim.abualsondos@asu.edu.bh (I. A. Abu AlSondos) 
(EOU) toward consumer perception for using m-commerce system in coming future. In this research, the researcher tries to answering the following questions:

1. Is there any relationship between perceived EOU and CPSQ?

2. Is there any relationship between PCC and CPSQ?

Thus, this study will identify the effect of service quality dimension (perceived cognitive control), and system quality dimension (perceived EOU) and how they affect the customer perceived service quality. Based on that, the researcher attempts to answer the following objectives:

1. To identify any kind of relationship between perceived EOU and CPSQ.

2. To investigate any kind of relationship between PCC and CPSQ.

Table 1 explains briefly the key definitions of the research constructs.

\section{Table 1}

Key Terms Definitions

\begin{tabular}{cl}
\hline Construct & \multicolumn{1}{c}{ Definition } \\
\hline $\begin{array}{c}\text { Customer Perceived Service } \\
\text { Quality }\end{array}$ & "Consumers' judgment about a business's overall distinction or dominance" (Parasura- \\
man, Zeithaml \& Berry, 1988). & "The degree to which the prospective user expects the target system to be free of effort" \\
Perceived Ease of use & (Davis, 1989). \\
$\begin{array}{c}\text { Perceived Cognitive } \\
\text { control }\end{array}$ & "The ability of controlling the customer's decision in using m-commerce service" (Bateson, \\
\hline
\end{tabular}

\section{Theoretical Background}

There is no doubt that commerce is an important factor that can effectively boost the economy of any nation. The traditional form of commerce ( $\mathrm{t}$-commerce) is the shops setting, where the providers and customers interact with each other, and this is the most common form of commerce. Some individuals may find it difficult to go to the shop because it is too far for them; some of them may be physically handicapped and some of them may work during the day with no chance to leave their jobs to go to the shops. Under this title researcher goes through while we did a hotspot on the literature on e-marketing research, and how the consumer perceived the SQ.

\subsection{The Implication of M-Commerce in Many Sectors}

The commercial business transactions, before this present time are provided only through electronic media. The reports nowadays show that the percentage of mobile phone users exceeds one-third of the world, and the rising number of mobile phone users assists on to find a new way for commercial businesses, and transactions. Thus, the m-commerce will open a new way of doing commercial (Sadi, Azad \& Noorudin, 2010; Tiwari \& Buse, 2007). Tiwari and Buse (2007) presented some of the mobile applications as we can notice in Table 1 as follows:

\section{Table 1}

Mobile Commerce services and Applications

\begin{tabular}{|c|c|c|}
\hline S.L & Mobile Commerce Services & Mobile Commerce Applications \\
\hline 1. & Mobile Accounting, Mobile Brokerage, Mobile Financial Information & M-Banking \\
\hline 2. & $\begin{array}{l}\text { Mobile Gaming, Downloads (music and ring tones) Downloads (video and digital images) Locations- } \\
\text { based Entertainment Service }\end{array}$ & M-Entertainment \\
\hline 3. & $\begin{array}{l}\text { Current Affairs, Travel Information \& Tracking Services, Mobile Search Engines and Directories of } \\
\text { Mobile Offices }\end{array}$ & Mobile Information Services \\
\hline 4. & Mobile Couponing, Direct Marketing, Mobile Newsletters, Organization of Mobile Events & M-Marketing \\
\hline 5. & Mobile Purchasing of goods & M-Shopping \\
\hline 6. & Public Transport, Cinema Booking & M-Ticketing \\
\hline 7. & m-Diagnosis, m-Prescription, M-Referencing, m-Appointment & M-Health \\
\hline 8. & m-Purse, m-wallet, Micro payment \& Macro payment & M-Payment \\
\hline 9. & $\begin{array}{l}\text { Remote Diagnosis and maintenance of Vehicles, Navigation Services, Vehicle Tracking and Theft pro- } \\
\text { tection, Emergency Services }\end{array}$ & Telematics Services \\
\hline
\end{tabular}

Source: Sadi, Azad and Noorudin (2010)

\subsection{Definition and Dimensions of e-SQ}

After reviewed the literature related to SQ, many previous studies used interchangeably the term of SQ and online SQ broadly as the researcher found (Piccoli et al., 2004; Zeithaml Parasuraman \& Malhotra, 2002; Lee \& Lin, 2005; Aladwani \& Palvia, 2002; Riel et al., 2001). Zeithaml et al. (2002) were the pioneers who introduced the concept of e-SQ and examined the SQ 
of websites, moreover to that, they investigated the role of SQ delivery to customers. Based on the previous definition (Zeithaml et al., 2002) they argued that high-quality websites have to offer a strong service to the consumer to confidently and comfortably do shopping, and expecting reliable service as well as fast delivery. So, to achieve that, corporations have to pay attention more to consumer perception about service quality. Thus, in this study the researcher will have a look to the service quality dimension variable "perceived cognitive control (PCC)", and system quality dimension variable "ease of use (EOU)".

\subsection{Service Quality Dimensions}

Perceived control depicts a cognitive state of flow experience and generally refers to the belief that the person has, at his or her disposal, a response that can influence an event (Ajzen, 1991). Among others subtle dimensions of perceived control (Ajzen, 1991), cognitive control is said to be an essentiality. Cognitive control requires a person to predict probable sequences of an event and also understand the implications of those consequences. It closely resembles the script theory model (Bateson, 1985). Cognitive control reduces uncertainty (Imada \& Nageishi, 1982). It increases the service value perceived by the customers (Bateson, 1985). Also, it clarifies a situation, particularly regarding the need for service involvement (Botvinick et al., 2001). In a retail setting, a customer's perceived cognitive control should evoke affect, because perceived control is closely associated with the customer's judgment of whether the environment will facilitate or frustrate his or her goal achievement (Ward \& Barnes, 2001). Previous researches identified perceived cognitive control as an important and desirable feature of self-service (Dabholkar \& Bagozzi, 2002; Meuter et al., 2000). Bateson (1985) stated that, perceived cognitive control has the ability of controlling the customer's decision in using m-commerce service. This position thus supports the claim that perceived cognitive control influences predicting probable event sequences. In e-retailing, such controls can be from a customer's perception of his or her ability to navigate the vendor's website effectively, and anticipates how the site will respond to his or her input or request (Novak et al., 2000). In online shopping, perceived cognitive control is observed when customers visits the vendor's site with the knowledge of what is expected when they click on a link. It is opined that the customers previously have a good knowledge about how a transaction can be completed within a normal timeframe, or anticipate the information they will receive upon completing a transaction (Dabholkar \& Bagozzi, 2002; Ding et al., 2007). Based on the explanation in above service quality variable dimension (PCC) the researcher hypothesizes the following:

$\mathbf{H}_{1}$ : There is a significant positive relationship between perceived cognitive control and overall customer perceived service quality.

\subsection{System Quality Dimensions}

Davis et al. (1992) defined ease of use as "the degree to which a person believes that using a particular system would be free of effort". Teo (2001) defined it as "the degree to which the user expects the use of the system to be user friendly". The ISO 20000 defines ease of use as "the extent to which a product can be used by specified users to achieve specified goals with effectiveness, efficiency and satisfaction in a specified context of use" (ISO, 1998). Nielsen (1996), pointed out that it can be measured by learnability, efficiency, memorability, low errors, and subjective satisfaction. However, Loiacono et al. (2002), considered ease of understanding and ease of navigation as two distinct aspects of ease of use when applied to the Web. Additionally, Dabholkar (1996) suggested that users may be concerned with:

a) saving actual effort; and

b) Reducing social risk, including avoiding the appearance of foolishness when struggling to use a system.

In the m-commerce environment, what can be used to describe adoption and use of a system increases if there is an ease when the system is used to find the customers' needs, and support services are available (Uther, 2002; Costabile et al., 2005). In summary, "ease of use" plays a vital role for customers' perceived mobile SQ (Chiu et al., 2005; Costabile et al., 2005, Papanikolaou \& Mavromoustakos, 2006; Udo, Bagchi \& Kirs, 2010; Lin \& Hsieh, 2011). The small screen of mobile devices demands special requirements of the user interface usability. If an m-commerce system is not usable, the customer is forced to spend much more time to understand software functionality, rather than to understand how to carry out commercial transaction and what available in its contents. Based on the explanation in above system quality variable dimension (EOU) the researcher hypothesizes hypotheses as shown in the following:

$\mathbf{H}_{2}$ : There is a significant positive relationship between ease of use and overall customer perceived service quality.

\section{Research Framework Development}

From the prior SQ studies, SQ was determined to actually be composed of, at least, two dimensions: core (outcome) and relational (process). These dimensions are briefly described below.

a) Core (Outcome) quality - is the basic service contracted for or promised; and centers around "What is delivered".

b) Relational (Process) quality - lies in the way in which the service is delivered; and centers around "How it is delivered". 
The majority of the dimensions were extracted from the initial study analysis. This study found that m-commerce is a new area of research; most of the dimensions are new in the sense of this area of study, as it is very difficult to find related studies, supported by evidence, that focus on SQ, customer satisfaction, and their influences on customer behavior intentions in the m-commerce environment; but similarities between mobile and e-services can be expected since both are Internet-based. In this research, much attention is paid to the measurement model of SQ in m-commerce based on the well-known SERVQUAL model. Many previous studies related to SQ suggested that it is necessary to add and modify items of the SERVQUAL scale, developed by Parasuraman et al., (1985, 1988), and to create a unique and comprehensive conceptual model of SQ, depending on the nature of the service sector under investigation (Carman, 1990; Cronin \& Taylor, 1992, 1994; Finn \& Lamb, 1991; Parasuraman \& Grewal, 2000). Based on this suggestion, this study proposes a multi-dimensional model of SQ for m-commerce and will examine the relationships between SQ and other significant constructs. The comprehensive in-depth discussions mentioned above provide us with a foundation for developing the theoretical model for how service quality dimension variable "perceived cognitive control (PCC)", and system quality dimension variable "ease of use (EOU)", and their impacts on customer perceived service quality as presented in Fig. 1:

\section{System Quality Dimension $\quad$ Service Quality Dimension}

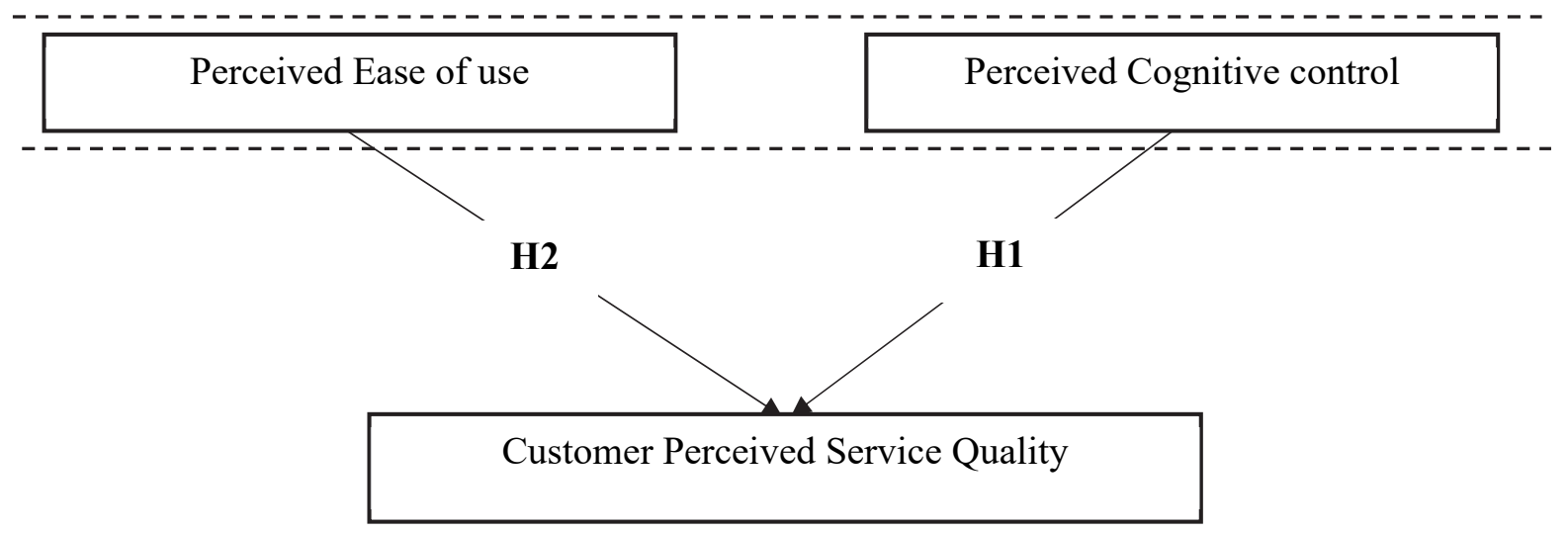

Fig. 1. Research Framework

This research tries to investigate the factor affecting customer perception toward using m-commerce in future, those factors (perceived cognitive control), and (ease of use), a quantitative technique and collecting data among students in AOU.

\section{Data Collection and Sample}

Students and employees of university was the source of this research, as previous research mentioned that the in the nature of students, they are more related to the mobile services (Kinnally et al., 2008). The researcher distributed 870 questionnaires to the targeted sample and the number of questionnaires returned and used as source of analysis was 618. For the purpose of developing the reliability, structural equations modeling smart PLS 2.0 was used in this study. PLS was used to test the hypotheses of this study as well.

\section{Model Measurement}

To strengthen the instrument of the measurement items, construct validity as well as content validity have been done for those purposes, as we noticed below:

\section{Content Validity}

In this study all the measure constructs used should show a high level of loadings in their respective constructs this is what content validity of construct mean. Previous literature was defined multivariate analysis as that, the measured constructs should have a high load compared with the other constructs in same column and row. Thus, factor loading should be used to evaluate the content validity (Hair et al., 2010; Chin, 1998). As we seen in Table 2 and Table 3, we notice that all variables positively loaded on their respective constructs, that's confirmed the required content validity in the measurement model used possesses. 
Table 2

Cross Loadings of the Items

\begin{tabular}{llccc}
\hline Constructs & Items & PCC & EOU & CPSQ \\
\hline \multirow{3}{*}{ Perceived Cognitive Control } & PCC1 & $\mathbf{0 . 8 2 5}$ & 0.447 & 0.381 \\
& PCC2 & $\mathbf{0 . 8 7 4}$ & 0.449 & 0.367 \\
& PCC3 & $\mathbf{0 . 8 7 6}$ & 0.513 & 0.408 \\
\hline & EOU1 & 0.486 & $\mathbf{0 . 7 9 7}$ & 0.493 \\
Ease of Use & EOU2 & 0.421 & $\mathbf{0 . 7 9 2}$ & 0.451 \\
& EOU3 & 0.453 & $\mathbf{0 . 8 1 8}$ & 0.494 \\
& EOU4 & 0.454 & $\mathbf{0 . 7 9 2}$ & 0.440 \\
& EOU5 & 0.349 & $\mathbf{0 . 7 3 7}$ & 0.531 \\
\hline & OVSQ1 & 0.274 & 0.404 & $\mathbf{0 . 7 6 0}$ \\
& OVSQ2 & 0.390 & 0.466 & $\mathbf{0 . 7 9 7}$ \\
\hline
\end{tabular}

Table 3

Significance Level of Factor Loadings

\begin{tabular}{llcccc}
\hline Constructs & Items & Loadings & $\begin{array}{c}\text { Standard Error } \\
\text { (STERR) }\end{array}$ & T Value & P Value \\
\hline \multirow{3}{*}{ Perceived Cognitive Control } & PCC1 & 0.825 & 0.023 & 36.574 & 0.000 \\
& PCC2 & 0.874 & 0.015 & 59.351 & 0.000 \\
& PCC3 & 0.876 & 0.018 & 49.974 & 0.000 \\
\hline \multirow{3}{*}{ Ease of Use } & EOU1 & 0.797 & 0.018 & 43.872 & 0.000 \\
& EOU2 & 0.792 & 0.023 & 34.022 & 0.000 \\
& EOU3 & 0.818 & 0.016 & 51.871 & 0.000 \\
\hline \multirow{3}{*}{ Customer Perceived Service } & EOU4 & 0.792 & 0.021 & 38.205 & 0.000 \\
Quality & EOU5 & 0.737 & 0.020 & 36.310 & 0.000 \\
& OVSQ1 & 0.797 & 0.018 & 43.872 & 0.000 \\
& OVSQ2 & 0.792 & 0.023 & 34.022 & 0.000 \\
\hline
\end{tabular}

\subsection{Convergent Validity of Constructs}

Convergent validity has been defined by previous researchers as the indication of the extent which a group of items converges for measuring a specific construct (Bagozzi \& Yi, 1988; Hair et al., 2010). The composite reliability should exceed more than cut off value which is CR> 0.7 as we notice the values in the Table 4 below, here in this study the least value of CR for all constructs is greater than 0.837 which means CR is applicable. Moreover, according to Fornell and Larcker (1981) and Hair et al. (2010) the average variance extracted (AVE) value should exceed 0.5 and here the value of AVE ranged among 0.566 to 0.738 which indicates a good level of construct validity related to the used measures (Barclay et al., 1995).

Table 4

Convergent Validity of Constructs

\begin{tabular}{|c|c|c|c|c|c|}
\hline Constructs & Items & Loading & Cronbach's Alpha & Composite Reliability & $\mathrm{AVE}^{\mathrm{b}}$ \\
\hline \multirow[t]{5}{*}{ Ease of use } & EOU1 & 0.797 & \multirow[t]{5}{*}{0.847} & \multirow[t]{5}{*}{0.891} & \multirow[t]{5}{*}{0.620} \\
\hline & EOU2 & 0.792 & & & \\
\hline & EOU3 & 0.818 & & & \\
\hline & EOU4 & 0.792 & & & \\
\hline & EOU5 & 0.737 & & & \\
\hline \multirow[t]{4}{*}{ Customer Perceived Service Quality } & OVSQ1 & 0.760 & \multirow[t]{4}{*}{0.738} & \multirow[t]{4}{*}{0.837} & \multirow[t]{4}{*}{0.566} \\
\hline & OVSQ2 & 0.797 & & & \\
\hline & OVSQ3 & 0.828 & & & \\
\hline & OVSQ4 & 0.605 & & & \\
\hline \multirow[t]{3}{*}{ Perceived Cognitive Control } & $\mathrm{PCC} 1$ & 0.825 & \multirow[t]{3}{*}{0.822} & \multirow[t]{3}{*}{0.894} & \multirow[t]{3}{*}{0.738} \\
\hline & $\mathrm{PCC} 2$ & 0.874 & & & \\
\hline & PCC3 & 0.876 & & & \\
\hline
\end{tabular}

\subsection{The Hypotheses Testing}

The measurement model was built, then test the hypotheses by PLS Bootstrapping, the number of returned questionnaires that can be used for analysis was 618 . 
Table 5

Results of the Hypotheses Testing

\begin{tabular}{ccccccc}
\hline No. & Hypotheses & Path Coefficient & $\begin{array}{c}\text { Standard Error } \\
(\text { STERR })\end{array}$ & T value & P value & Decision \\
\hline 1 & PCC $\rightarrow$ OVSQ & $-0.091^{* * *}$ & 0.036 & 2.537 & 0.006 & Supported \\
2 & EOU $\rightarrow$ OVSQ & $0.091^{* *}$ & 0.050 & 1.825 & 0.034 & Supported \\
\hline
\end{tabular}

The results show that there is a significant and a positive effect between perceived cognitive control (PCC) and customer perceived service quality (CPSQ) when the level of significance is one percent $(\beta=-0.091, t=2.537, p<0.01)$. Finally, the result among ease of use and customer perceived service quality yields (CPSQ) is $(\beta=0.091, \mathrm{t}=1.825, \mathrm{p}<0.05)$. Thus, all results agree with hypotheses of that research $\mathrm{H} 1$, as well as $\mathrm{H} 2$ as reported in Table 5.

\section{Discussion and Conclusion}

The main objective of this study was to check the effect of ease of use, and perceived cognitive control on customers consumer perception for using m-commerce system, Importantly this study has been expanded in the area of SERVQUAL, whereas previous researches focused on the same topic, the model was created by summarizing many studies related to m-commerce, information systems, and SERVQUAL as well, moreover to that, this study can be considered between the first studies which focuses in the factors that can influence consumers towards $\mathrm{m}$-commerce systems especially for purchasing purposes.

Perceived cognitive control is therefore assumed to be very crucial for the m-commerce users since it indicates that customers have the necessary skills and the technological background that are necessary to purchase online and demonstrating a full ability of using mobile commerce operations. To confirm this assumption, respondents were classified into different groups at different levels and education in m-commerce where a statistical test was implemented. It was demonstrated that experienced $\mathrm{m}$-commerce users were more likely to show a complete understanding of online purchases.

The finding of this study reveals that ease of use (EOU) has significant and positive relationship with consumer perception for using m-commerce system (CPSQ), which makes H2 to be supported. Moreover, the outcomes also reveal that positive effect of ease of use (EOU) on overall perceived service quality (OVSQ) could be as a result of ability of the m-commerce site to easily meet with the expectations of the users. The providers need to make $\mathrm{m}$-commerce easier to use by educating the customers in simple ways to help them go through m-commerce activities.

\section{References}

Ajzen, I. (1991). The theory of planned behavior. Organizational Behavior and Human Decision Processes, 50(2), $179-211$. Aladwani, A. M., \& Palvia, P. C. (2002). Developing and validating an instrument for measuring user-perceived web quality. Information \& Management, 39(6), 467-476.

Bagozzi, R. P., \& Yi, Y. (1988). On the evaluation of structural equation models. Journal of the academy of Marketing Science, 16(1), 74-94.

Barclay, D., Higgins, C., \& Thompson, R. (1995). The partial least squares (PLS) approach to causal modeling: Personal computer adoption and use as an illustration. Technology Studies, 2(2), 285-309.

Bateson, J. E. (1985). Self-service consumer: An exploratory study. Journal of Retailing, 61(3), 49-76.

Botvinick, M. M., Braver, T. S., Barch, D. M., Carter, C. S., \& Cohen, J. D. (2001). Conflict monitoring and cognitive control. Psychological Review, 108(3), 624-652.

Carman, J. M. (1990). Consumer perceptions of service quality: An assessment of the SERVQUAL dimensions. Journal of Retailing, 66(1), 33-55.

Chin, W. W. (1998). The partial least squares approach to structural equation modeling. Modern Methods for Business Research, 295(2), 295-336.

Chiu, C.-M., Hsu, M.-H., Sun, S.-Y., Lin, T.-C., \& Sun, P.-C. (2005). Usability, quality, value and e-learning continuance decisions. Computers \& Education, 45(4), 399-416.

Costabile, M., De Marsico, M., Lanzilotti, R., Plantamura, V., \& Roselli, T. (2005). On the usability evaluation of e-learning applications. Paper presented at the 38th Hawaii International Conference on System Sciences, Hawaii.

Cronin Jr, J. J., \& Taylor, S. A. (1992). Measuring service quality: a reexamination and extension. The Journal of Marketing, $56(3), 55-68$.

Cronin Jr, J. J., \& Taylor, S. A. (1994). SERVPERF versus SERVQUAL: reconciling performance-based and perceptionsminus-expectations measurement of service quality. The Journal of Marketing, 58(2), 125-131.

Dabholkar, P. A. (1996). Consumer evaluations of new technology-based self-service options: an investigation of alternative models of service quality. International Journal of Research in Marketing, 13(1), 29-51.

Dabholkar, P. A., \& Bagozzi, R. P. (2002). An attitudinal model of technology-based self-service: moderating effects of consumer traits and situational factors. Journal of the Academy of Marketing Science, 30(3), 184-201.

Davis, F. D., Bagozzi, R. P., \& Warshaw, P. R. (1992). Extrinsic and intrinsic motivation to use computers in the workplace. Journal of Applied Social Psychology, 22(14), 1111-1132. 
Ding, X., Verma, R., \& Iqbal, Z. (2007). Self-service technology and online financial service choice. International Journal of Service Industry Management, 18(3), 246-268.

Finn, D. W., \& Lamb, C. W. (1991). An evaluation of the SERVQUAL scales in a retailing setting. Advances in Consumer Research, 18(1), 483-490.

Fornell, C., \& Larcker, D. F. (1981). Evaluating structural equation models with unobservable variables and measurement error. Journal of Marketing Research, 5(9), 39-50.

Hair, J. J. F., Black, W. C., Babin, B. J., \& Anderson, R. E. (2010). Multivariate Data Analysis. A Global Perspective. London: Pearson Education.

Imada, H., \& Nageishi, Y. (1982). The concept of uncertainty in animal experiments using aversive stimulation. Psychological Bulletin, 91(3), 573-588.

ISO, D. (1998). Ergonomic Requirements for Office Work with Visual Display Terminal. Part 11: Guidance on specifying and measuring usability. International Organization for Standardization.

Kinnally, W., Lacayo, A., McClun, S. and Sapolsky, B. (2008), Getting up on the download: college students' motivation for acquiring music via the web. New Media Society, 10(3), 893-913.

Klopfer, E., Osterweil, S., Groff, J., \& Haas, J. (2009). Using the technology of today in the classroom today: The instructional power of digital games, social networking, and simulations and how teachers can leverage them. The Education Arcade, 4(2), 1-20.

Lee, G. G., \& Lin, H. F. (2005). Customer perceptions of e-service quality in online shopping. International Journal of Retail \& Distribution Management, 33(2), 161-176.

Loiacono, E. T., Watson, R. T., \& Goodhue, D. L. (2002). WebQual: A measure of website quality. Marketing theory and applications, 13(3), 432-438.

Mallat, N., Rossi, M., Tuunainen, V. K., \& Oorni, A. (2009). The impact of use context on mobile services acceptance: The case of mobile ticketing. Information \& Management, 46(3), 190-195.

Meuter, M. L., Ostrom, A. L., Roundtree, R. I., \& Bitner, M. J. (2000). Self-service technologies: understanding customer satisfaction with technology-based service encounters. The Journal of Marketing, 64(3), 50-64.

Nielsen, J. (1996). Usability metrics: Tracking interface improvements. IEEE software, 13(6), 12-28.

Novak, T. P., Hoffman, D. L., \& Yung, Y. F. (2000). Measuring the customer experience in online environments: A structural modeling approach. Marketing Science, 19(1), 22-42.

Papanikolaou, K., \& Mavromoustakos, S. (2006). Critical success factors for the development of mobile learning applications. Paper presented at the 24th IASTED International Multi-Conference Internet and Multimedia Systems and applications Innsbruck, Austria.

Parasuraman, A., Zeithaml, V. A., \& Berry, L. L. (1985). A conceptual model of service quality and its implications for future research. The Journal of Marketing, 49(5), 41-50.

Parasuraman, A., Zeithaml, V. A., \& Berry, L. L. (1988). SERVQAL: A Multiple Item Scale For Measuring Consumer Perceptions Of Service Quality. Journal of Retailing, 64(1), 12-40.

Parasuraman, A., \& Grewal, D. (2000). The impact of technology on the quality-value-loyalty chain: a research agenda. Journal of the Academy of Marketing Science, 28(1), 168-174.

Piccoli, G., Brohman, M. K., Watson, R. T., \& Parasuraman, A. (2004). Net-Based Customer Service Systems: Evolution and Revolution in Web Site Functionalities. Decision Sciences, 35(3), 423-455.

Riel, A. C., Liljander, V., \& Jurriens, P. (2001). Exploring consumer evaluations of e-services: a portal site. International Journal of Service Industry Management, 12(4), 359-377.

Sadi, A., Azad, I., \& Noorudin, M. (2010). The prospects and user perceptions of m-banking in the Sultanate of Oman. Journal of Internet Banking and Commerce, 15(2), 1-11.

Sadi, A., \& Noordin, M. F. (2011). Factors influencing the adoption of m-commerce: An exploratory analysis. Paper presented at the 2011 International Conference on Industrial Engineering and Operations Management Kuala Lumpur, Malaysia.

Teo, T. S. (2001). Demographic and motivation variables associated with Internet usage activities. Internet Research: Electronic Networking Applications and Policy, 11(2), 125-137.

Tiwari, R., \& Buse, S. (2007). The Mobile Commerce Prospects: A strategic analysis of opportunities in the banking sector. Hamburg, Germany: Hamburg University Press.

Udo, G. J., Bagchi, K. K., \& Kirs, P. J. (2010). An assessment of customers'e-service quality perception, satisfaction and intention. International Journal of Information Management, 30(6), 481-492.

Uther, M. (2002). Mobile Internet usability: what can'mobile learning'learn from the past? Paper presented at the IEEE International Workshop on Wireless and Mobile Technologies in Education (WMTE'02).

Ward, J. C., \& Barnes, J. W. (2001). Control and affect: the influence of feeling in control of the retail environment on affect, involvement, attitude, and behavior. Journal of Business Research, 54(2), 139-144.

Zeithaml, V. A., Parasuraman, A., \& Malhotra, A. (2002). Service quality delivery through web sites: a critical review of extant knowledge. Journal of the Academy of Marketing Science, 30(4), 362-375. 


\section{Appendix}

Measurement Scale of Constructs

1.0 This section is aimed at understanding the Perceived Cognitive Control of mobile commerce (m-commerce) service.

1. I know what to expect in following steps. $\quad 1 \quad 2 \quad 3 \quad 4 \quad 5$

2. I know how long it takes to complete the transaction.

$\begin{array}{lllll}1 & 2 & 3 & 4 & 5\end{array}$

3. I know what information will be provided in each page.

$\begin{array}{lllll}1 & 2 & 3 & 4 & 5\end{array}$

2.0 This section is aimed at understanding the Ease of use of mobile commerce (m-commerce) service.

1. The m-commerce is easy to use.

2. The m-commerce makes it easy for me to find the content I need.

3. The content provided by the m-commerce is easy to understand.

4. The m-commerce is user-friendly.

5. The operation of the m-commerce is stable.

\begin{tabular}{lllll}
1 & 2 & 3 & 4 & 5 \\
1 & 2 & 3 & 4 & 5 \\
1 & 2 & 3 & 4 & 5 \\
1 & 2 & 3 & 4 & 5 \\
1 & 2 & 3 & 4 & 5 \\
\hline
\end{tabular}

3.0 This section is aimed at understanding the Customer Perceived Service Quality of mobile commerce (m-commerce) service.

\begin{tabular}{llllll}
\hline 1. Overall, the services provided by m-commerce have excellent quality. & 1 & 2 & 3 & 4 & 5 \\
2. The service quality provided by m-commerce matches my expectations. & 1 & 2 & 3 & 4 & 5 \\
3. The m-commerce delivers superior service in every way. & 1 & 2 & 3 & 4 & 5 \\
\hline 4. The m-commerce offers a very competitive service. & 1 & 2 & 3 & 4 & 5 \\
\hline
\end{tabular}

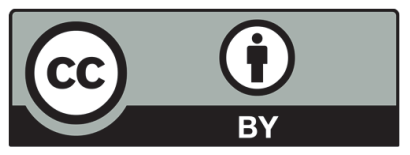

(C) 2020 by the authors; licensee Growing Science, Canada. This is an open access article distributed under the terms and conditions of the Creative Commons Attribution (CC-BY) license (http://creativecommons.org/licenses/by/4.0/). 